
\title{
$\begin{array}{ll}\text { Research Square } & \begin{array}{l}\text { Preprints are preliminary reports that have not undergone peer review. } \\ \text { They should not be considered conclusive, used to inform clinical practice, } \\ \text { or referenced by the media as validated information. }\end{array}\end{array}$
}

\section{COVID-19 Space-time Cluster Detection in Ethiopia Using Retrospective Analysis}

KALEAB TESFAYE TEGEGNE ( $\sim$ kaleabtesfaye35@gmail.com )

Deaprtment of Public Health , Hawassa College of Health Science, Hawassa

ELENI TESFAYE TEGEGNE

College of Medicine and Health Science, School of Nursing , University of Gondar , Gondar

MEKIBIB KASSA TESSEMA

Leishmania Research and Treatment Center, University of Gondar, Gondar

GELETA ABERA

Deaprtment of Public Health, Hawassa College of Health Science, Hawassa

BERHANU BIFATO

Deaprtment of Public Health, Hawassa College of Health Science, Hawassa

KEBEBUSH GEBREMICHAEL

Deaprtment of Public Health , Hawassa College of Health Science, Hawassa

ALELIGN TADELE ABEBE

Department of Medical Laboratory Technology, Hawassa College of Health Science, Hawassa

ABIYU AYALEW ASSEFA

Deaprtment of Public Health, Hawassa College of Health Science, Hawassa

ANDUALEM ZENEBE

Deaprtment of Public Health , Hawassa College of Health Science, Hawassa

WOSENYELEH SEMEON BAGAJJO

Dean of Hawassa College of Health Science, Hawassa

MUSIE RIKE

Research and Publication Directorate, Hawassa College of Health Science, Hawassa

BELAYNEH FELEKE WELDEYES

Department of Midwifery, Hawassa College of Health Science, Hawassa

ARGAW GETACHEW ALEMU

Tenta Gashena Road Project Coordinator

\section{Research Article}

Keywords: COVID 19, SaTScan, Space-time clustering, Ethiopia

Posted Date: January 20th, 2022

DOI: https://doi.org/10.21203/rs.3.rs-1231876/v2

License: @ (i) This work is licensed under a Creative Commons Attribution 4.0 International License. Read Full License 


\section{Abstract}

Background: As of the 31st of January 2021, there had been 102,399,513 confirmed cases of COVID-19 worldwide, with 2,217,005 deaths reported to WHO

The goal of this study is to uncover the spatiotemporal patterns of COVID 19 in Ethiopia, which will aid in the planning and implementation of essential preventative measures.

Methods We obtained data on COVID 19 cases reported in Ethiopia from November 23 to December 29, 2021, from an Ethiopian health data website that is open to the public.

Kulldorff's retrospective space-time scan statistics were utilized to detect the temporal, geographical, and spatiotemporal clusters of COVID 19 at the county level in Ethiopia, using the discrete Poisson probability model.

Results: In Ethiopia, between November 23 and December 29, 2021, a total of 22,199 COVID 19 cases were reported.

The COVID 19 cases in Ethiopia were strongly clustered in spatial, temporal, and spatiotemporal distribution, according to the results of Kulldorff's scan. statistics

The most likely Spatio-temporal cluster $(L L R=70369.783209, R R=412.48, \mathrm{P} 0.001)$ was mostly concentrated in Addis Ababa and clustered between 2021/11/1 and 2021/11/30.

Conclusion: From November 23 to December 29, 2021, this study found three large COVID 19 space-time clusters in Ethiopia, which could aid in future resource allocation in high-risk locations for COVID 19 management and prevention.

\section{Introduction}

As of the 31st of January 2021, there had been 102,399,513 confirmed cases of COVID-19 worldwide, with 2,217,005 deaths reported to WHO (1)

Geographic Information Systems (GIS) and scan statistics are increasingly being used to evaluate and detect geographical and spatiotemporal changes and clustering of diseases, resulting in more information in terms of disease dispersion (2)

COVID 19 has been found to cluster spatially and spatiotemporally in several investigations. (3-13)

The Geographic Information System (GIS) is a useful tool for displaying and evaluating geographic features based on epidemiology data. $(14-15)$

By giving scientific knowledge, establishing spatial relationships with other parameters, and identifying transmission patterns and clustering, GIS can be utilized in conjunction with spatial statistics to help limit the epidemic. (16-19)

COVID 19 reports from Ethiopia suggest regional differences in trends and case notification rates, while it's unclear if these variations are caused by the disease's geographical and spatiotemporal pattern,..(20)

As a result, regardless of the illness burden in the community, the national COVID 19 program executes comparable Interventions have been inconsistent across places, which could be due to a lack of understanding of the disease's distribution pattern in several circumstances

Furthermore, except for a single paper describing a geographic study of vulnerability to infection, case severity, and death, information concerning the disease's spatial distribution is scarce. (21)

Understanding the disease's geographical pattern and spatiotemporal fluctuations across larger geographic settings, such as urban-rural areas, could aid policy and decision-making in resource-constrained situations like Ethiopia

As a result, we want to investigate the disease's spatiotemporal clustering in Ethiopia over the last month.

\section{Methods}

\section{Study area and setting}


Ethiopia's GPS coordinates are $9.1450^{\circ} \mathrm{N}$ and $40.4897^{\circ} \mathrm{E}$.

Ethiopia is the 26th largest country in terms of physical size, with a total area of 426,400 square miles.

The country has a length of 1,018 miles and a width of 980 miles.

Ethiopia has a land area of 90.5 percent and a sea area of 9.5 percent.

In other terms, Ethiopia's entire land area is 386,102 square miles and its total water area is 40,298 square miles. (22)

Ethiopia's population is over 117 million people. (23)

There are eleven regional states and two chartered cities in Ethiopia: Addis Ababa, the capital, and Dire Dawa, which was chartered in 2004. (24) (Fig 1).

\section{Data collection and analysis}

From November 23 through December 29, 2021, data was collected.

The data came from an Ethiopian health data website that is free to the general public (20).

After importing the data into Microsoft Excel and analyzing it with SaTscan software version 10, we used ArcGIS 10.3 to illustrate the relative risk of COVID 19 in high-risk cluster sites

\section{Statistical analysis}

To uncover COVID 19's temporal, geographical, and space-time clusters, as well as determine whether the geographic grouping was due to chance or not, we used Kulldorff's space-time scan statistical analysis (25)

The scan statistics do a cluster analysis and determine cluster size and locations using Monte Carlo Simulation, as well as compute the relative risk (RR) and generate a P-value.

\section{Spatial analysis}

With the assumption that the number of cases at each site was Poisson distributed with a known population at risk, the discrete Poisson model, as well as the number of cases (COVID 19 instances), population, and coordinates, were used as input files.

Using scan circles of various sizes, including the default value in scan statistics, the most likely spatial clusters of COVID 19 were found. The maximum spatial cluster size was calculated using an upper limit of $50 \%$ of the population at risk.

The likelihood ratio was utilized to compute relative risk (26), and the most likely and secondary clusters were determined and reported when the P-value was less than 0.05 .

The results of the investigation were displayed in tables and on maps to illustrate where the sickness had occurred at particularly high rates.

\section{Space-time analysis}

The space-time scan statistic approach uses a cylindrical window with a circular geographic foundation that is related to space and height according to time for potential clusters. (26)

COVID 19's RR was supposed to be the same inside the glass as it was outside.

The number of occurrences in areas is Poisson-distributed based on a given risk population in the Poisson probability model. (26).

To establish the test of significance, the likelihood ratio test was compared to a null distribution created by a Monte Carlo Simulation.

The permutation count was set to 999, while the statistical significance was set at P0.05.

We ran a space-time investigation for the period 2021/11/23-2021/12/29 to see if there were any recent space-time clusters of the disease. 


\section{Results}

A total of 22,199 COVID 19 cases were reported from November 23 through December 29, 2021. In Ethiopia

Table 1. Spatial clustering of COVID 19 in Ethiopia from 2021/11/23-2021/12/29

\begin{tabular}{|c|c|c|c|c|c|c|c|c|}
\hline $\begin{array}{l}\text { Cluster } \\
\text { Type }\end{array}$ & Coordinates /Radius & $\mathrm{N}$ & Cluster Regions & $\begin{array}{l}\text { Observed } \\
\text { Case }\end{array}$ & $\begin{array}{l}\text { Expected } \\
\text { Case }\end{array}$ & $\mathrm{RR}$ & LLR & $\begin{array}{l}\mathrm{P} \text { - } \\
\text { value }\end{array}$ \\
\hline $\begin{array}{l}\text { Most likely } \\
\text { Cluster }\end{array}$ & $\begin{array}{l}9.005401 \mathrm{~N}, \\
38.763611 \mathrm{E} / \mathrm{o} \mathrm{km}\end{array}$ & 1 & Addis Ababa & 19772 & 874.23 & 198.72 & 56388.10451 & 0.001 \\
\hline $\begin{array}{l}\text { Secondary } \\
\text { Cluster } 1\end{array}$ & $\begin{array}{lr}6.661229 & \mathrm{~N}, \\
43.790845 \mathrm{E} / & 604.49 \\
\mathrm{~km} & \end{array}$ & 5 & $\begin{array}{l}\text { Somalia, Harar, Dire } \\
\text { Dawa, Oromia, Afar }\end{array}$ & 1793 & 11095.49 & 0.088 & 9150.429466 & 0.001 \\
\hline $\begin{array}{l}\text { Secondary } \\
\text { Cluster } 2\end{array}$ & $\begin{array}{l}11.663240 \quad \mathrm{~N}, \\
37.821903 \mathrm{E} / 0 \mathrm{~km}\end{array}$ & 1 & Amhara & 366 & 5449.19 & 0.052 & 4798.102396 & 0.001 \\
\hline $\begin{array}{l}\text { Secondary } \\
\text { Cluster } 3\end{array}$ & $\begin{array}{ll}6.033103 & \mathrm{~N}, \\
36.433828 & \\
\mathrm{E} / 319.05 \mathrm{~km} & \end{array}$ & 2 & SNNPR, Gambela & 268 & 3161.17 & 0.074 & 2441.304521 & 0.001 \\
\hline $\begin{array}{l}\text { Secondary } \\
\text { Cluster } 4\end{array}$ & $\begin{array}{l}6.661229 \mathrm{~N}, \\
43.790845 \mathrm{E} / 0 \mathrm{~km}\end{array}$ & 1 & Somalia & 0 & 1456.52 & 0 & 1506.498239 & 0.001 \\
\hline $\begin{array}{l}\text { Secondary } \\
\text { Cluster } 5\end{array}$ & $\begin{array}{l}14.032334 \mathrm{~N}, \\
38.316573 \mathrm{E} / 0 \mathrm{~km}\end{array}$ & 1 & Tigray & 0 & 1350.48 & 0 & 1393.301071 & 0.001 \\
\hline $\begin{array}{l}\text { Secondary } \\
\text { Cluster } 6\end{array}$ & $\begin{array}{ll}11.485999 & \mathrm{~N} \\
41.245999 \mathrm{E} / 0 \mathrm{~km} & \end{array}$ & 1 & Afar & 0 & 460.22 & 0 & 465.057428 & 0.001 \\
\hline $\begin{array}{l}\text { Secondary } \\
\text { Cluster } 7\end{array}$ & $\begin{array}{l}10.780289 \mathrm{~N}, \\
35.565786 \mathrm{E} / 0 \mathrm{~km}\end{array}$ & 1 & Benishangul Gumuz & 0 & 268.44 & 0 & 270.075601 & 0.001 \\
\hline
\end{tabular}

A total of eight statistically significant areas, comprising a total of 11 regions, were identified by spatial clustering analysis.

Addis Ababa has the highest proportion of high-risk locations, with a relative risk of more than three.

Addis Ababa. the region, $9.005401 \mathrm{~N}, 38.763611 \mathrm{E}(\mathrm{LLR}=56388.10451, \mathrm{P} 0.001)$ was found to be the center of the most likely cluster area (Figure 2)

With a radius of 0 kilometers, this circular area exclusively covered Addis Ababa.

The total number of COVID 19 cases was 19772, and the risk of COVID 19 was 198.72 times $(R R=198.72)$ higher in this location than it was elsewhere (Table 1)

Table 2. Temporal Clustering of COVID 19 cases In Ethiopia from 2021/11/23-2021/12/29

\begin{tabular}{|l|l|l|l|l|l|}
\hline uster Time Frame & Observed Cases & Expected Cases & RR & LLR & P-value \\
\hline $21 / 11 / 23-2021 / 12 / 1$ & 22,199 & 5399.76 & 0 & 31382.578351 & 0.001 \\
\hline
\end{tabular}

The temporal cluster analysis with time aggregation length of 7 days and time precision of day showed that COVID 19 cases were low from 2021/11/23-2021/12/1 (Figure 3)

The low aggregated period for COVID 19 was observed in all regions from 2021/11/23-2021/12/1 (LLR = 31382.578351, $P=0.001)$.

During this period from 2021/11/23-2021/12/1, a total of 22,199 COVID 19 cases were reported, and the risk of

COVID 19 was (RR = infinity) very low (Table 2). 
Table 3. Spatiotemporal clusters of COVID 19 in Ethiopia

\begin{tabular}{|c|c|c|c|c|c|c|c|c|c|}
\hline $\begin{array}{l}\text { Cluster } \\
\text { Type }\end{array}$ & $\begin{array}{l}\text { Cluster } \\
\text { Time } \\
\text { Frame }\end{array}$ & Coordinates /Radius & $\mathrm{N}$ & $\begin{array}{l}\text { Cluster } \\
\text { Countries }\end{array}$ & $\begin{array}{l}\text { Observed } \\
\text { Case }\end{array}$ & $\begin{array}{l}\text { Expected } \\
\text { Case }\end{array}$ & $\mathrm{RR}$ & LLR & $\begin{array}{l}\text { P- } \\
\text { value }\end{array}$ \\
\hline $\begin{array}{l}\text { Most } \\
\text { likely } \\
\text { Cluster }\end{array}$ & $\begin{array}{l}2021 / 11 / 1- \\
2021 / 11 / 30\end{array}$ & $\begin{array}{l}9.005401 \\
\mathrm{~N}, 38.763611 \mathrm{E} / 0 \mathrm{~km}\end{array}$ & 1 & $\begin{array}{l}\text { Addis } \\
\text { Ababa }\end{array}$ & 19772 & 429.95 & 412.48 & 70369.783209 & 0.001 \\
\hline $\begin{array}{l}\text { Secondary } \\
\text { Cluster } 1\end{array}$ & $\begin{array}{l}2020 / 12 / 1- \\
2021 / 12 / 31\end{array}$ & $\begin{array}{l}6.661229 \\
\mathrm{~N}, 43.790845 \\
/ 604.48 \mathrm{~km}\end{array}$ & 5 & $\begin{array}{l}\text { Somalia, } \\
\text { Harar, } \\
\text { Dire } \\
\text { Dawa, } \\
\text { Oromia, } \\
\text { Afar }\end{array}$ & 0 & 5638.69 & 0 & 6505.163412 & 0.001 \\
\hline $\begin{array}{l}\text { Secondary } \\
\text { Cluster } 2\end{array}$ & $\begin{array}{l}2020 / 12 / 1- \\
2021 / 12 / 31\end{array}$ & $\begin{array}{l}6.033103 \mathrm{~N}, 36.433828 \\
\mathrm{E} / 319.05 \mathrm{~km}\end{array}$ & 2 & $\begin{array}{l}\text { SNNPR, } \\
\text { Gambela }\end{array}$ & 0 & 1606.50 & 0 & 1667.593870 & 0.001 \\
\hline
\end{tabular}

Addis Ababa was the most likely spatiotemporal cluster location, and the high-risk period was from 2021/11/1-2021/11/30 (LLR = 70369.783209, P 0.001).

The area's center was Addis Ababa, which was located at $9.005401 \mathrm{~N}$ and $38.763611 \mathrm{E}$, with a radius of $0 \mathrm{~km}$ (Figure 4 )

During the period 2021/11/1-2021/11/30, a total of 19772 COVID 19 cases were recorded in this location, with an RR of 412.48 (Table3.)

\section{Discussion}

Kulldorff's scan statistical analysis was used to analyze the spatial, temporal, and spatiotemporal clusters of COVID 19 in Ethiopia from $2021 / 11 / 23$ to $2021 / 12 / 29$.

To our knowledge, no other study of this nature has been conducted in Ethiopia.

Our research found that the distribution of COVID 19 cases in Addis Ababa was highly space-time clustered.

Addis Ababa was the epicenter of the COVID 19 outbreak.

Multiple testing problems are taken into consideration in Kulldorff's retrospective scan statistics, which is known as the most powerful method for evaluating geographical and temporal distribution utilizing routinely obtained data (27).

This approach has been used to detect disease clusters all over the world (28-31)

The results of our temporal scanning revealed that COVID 19 had a low-risk phase between November 23, 2021, and December $29,2021$.

The spatiotemporal model utilized in this work examined both time and space distributions at the same time.

The time-space scanning model, as opposed to the distinct spatial and temporal scanning models, produces a conclusion that is closer to the real-world situation.

We discovered that COVID 19 instances were concentrated in Addis Ababa from 2021/11/23-2021/12/29 when we used this model to determine the Spatio-temporal distribution of COVID 19 in Ethiopia.

COVID 19 was more prevalent in Addis Ababa during this time than in other Ethiopian districts.

The causes for the great magnitude of COVID 19 in Addis Ababa are as follows:

Addis Ababa is Ethiopia's capital city, and it has a higher level of testing and quarantine coverage than the rest of the country.

Many people, including Ethiopian long-distance vehicle drivers, traders, and others, have been traveling from Djibouti to Ethiopia via the route that connects the Amhara area, Addis Ababa, and Oromia region since the commencement of the COVID-19 pandemic, mostly owing to geographical proximity (32)

SARS-CoV 2 infection is very dangerous for certain populations.

Page 5/11 
Sentinel monitoring attempts to detect the early introduction and spread of COVID-19 are especially well-suited for such populations, especially in areas with low vaccination coverage or where layered preventative techniques are not used.

Due to their high risk of exposure or severe illness, the CDC deems the ability to monitor COVID-19 incidence in the following populations to be particularly useful:

Health care workers, residents and staff members of long-term care facilities, incarcerated people, homeless people, and workers in highdensity work sites, students and staff members of kindergarten-grade 12 schools and institutions of higher education, incarcerated people, homeless people, and workers in high-density work sites (33-38)

Rising case detection rates can act as an early warning indicator that prevention methods in the facility and the larger community need to be reinforced or introduced.

Furthermore, strategic serial testing can aid in the prevention of SARS-CoV-2 transmission by quickly detecting asymptomatic cases, which are thought to account for at least $50 \%$ of SARS-CoV-2 transmission (39-40)

Further prevention and particular COVID 19 control methods should be addressed regarding the vaccine, testing, and prevention practices in other Ethiopian regions, according to our findings.

Our research also confirmed the use of spatial and temporal clustering analysis with ArcGIS and SaTScan in identifying significant COVID 19 space-time clusters in Ethiopia.

This could be utilized to develop COVID19 preventive initiatives at the county level.

However, the study's analysis was limited.

First and foremost, the data were studied at the county level, which is not the smallest administrative regionalization unit.

As a result, we can rule out several important elements.

Second, meteorological and socio-economic aspects were not taken into account in this study.

\section{Conclusion}

Using Kulldorff's retrospective scan statistic approaches, we examined the geographical, temporal, and space-time clusters of COVID 19 at the county level in Ethiopia from 201/11/23 to 2021/12/29.

The results of the space-time scanning revealed that Addis Ababa is at high risk for COVID 19.

These findings indicate that the Addis Ababa health office, Ethiopian Minister of Health, and Ethiopia Public Health Institute must implement preventive and control programs to reduce COVID 19 in Addis Ababa as soon as possible.

\section{Declarations}

Ethics approval and consent to participate: This research is based on secondary data from Ethiopia's COVID 19, which is publically available at https://ethiopianhealthdata.org > COVID-19 Ethiopia Case Tracker Dashboard (20)

Consent for publication: not applicable

Availability of data and materials: The paper includes all data.

Competing interests: There are no competing interests stated by the authors.

\section{Funding}

There was no financing available for this project

Contributions of the Authors: KTT was responsible for the original drafting of the manuscript's conceptualization, analysis, supervision, and development. 
Methodology, Discussion, and Data Analysis were all done by KTT, ETT, AGA, and MKT.

KTT, ETT, MKT, GA, BB, KG, AT, AAA, AZ, WSB, MR, BFW, and AGA assisted with data analysis, critically revised the work, and agreed to be held accountable.

\section{Acknowledgments}

We'd like to thank Hawassa College of Health Science for assisting us with this study project.

\section{References}

1. Wang Y, Hu M, Li Q, et al. (2020) Abnormal respiratory patterns classifier may contribute to the large-scale screening of people infected with COVID-19 accurately and unobtrusively. arXiv: 2002.05534

2. Cromley EK, McLafferty SL. GIS and Public Health. Second edition ed. New York: The Guilford Press; 2012

3. Manda, S.O.M.; Darikwa, T.; Nkwenika, T.; Bergquist, R. A Spatial Analysis of COVID-19 in African Countries: Evaluating the Effects of Socio-Economic Vulnerabilities and Neighbouring. Int. J. Environ. Res. Public Health 2021, 18, 10783. https://doi.org/10.3390/ ijerph182010783]

4. Jesri, N., Saghafipour, A., Koohpaei, A. et al. Mapping and Spatial Pattern Analysis of COVID-19 in Central Iran Using the Local Indicators of Spatial Association (LISA). BMC Public Health 21, 2227 (2021). https://doi.org/10.1186/s12889-021-12267-6

5. Ferreira, M. C. (2020). Spatial association between the incidence rate of COVID-19 and poverty in the São Paulo municipality, Brazil. Geospatial Health, 15(2). https://doi.org/10.4081/gh.2020.921

6. Islam J, Guo X, Ali MA, et al. Spatial pattern of COVID-19 in Bangladesh: an ecological study. BMJ Open 2021;11:e047566. doi:10.1136/ BMJ open-2020-047566

7. Schüler L, Calabrese JM, Attinger S (2021) Data-driven high-resolution modeling and spatial analyses of the COVID-19 pandemic in Germany. PLoS ONE 16(8): e0254660. https://doi.org/10.1371/journal.pone.0254660

8. Wang, W. Dong, K. Yang, et al Temporal and spatial analysis of COVID-19 transmission in China and its influencing factors internationals Journal of Infectious Diseases 105 (2021) 675-685

9. Zhu, D., Ye, X. \& Manson, S. Revealing the spatial shifting pattern of COVID-19 pandemic in the United States. Sci Rep 11, 8396 (2021). https://doi.org/10.1038/s41598-021-87902-8

10. Franch-Pardoa, I.; Napoletanob, B.; Rosete-Vergesa, F.; Billa, L. Spatial analysis and GIS in the study of COVID-19. A review. Sci.Total Environ. 2020, 739, 140033.

11. A. Hohl, E.M. Delmelle and M.R. Desjardins et al. Daily surveillance of COVID-19 using the prospective space-time scan statistic in the United States Spatial and Spatio-temporal Epidemiology 34 (2020) 10035

12. Batana, Yele Maweki; Nakamura, Shohei; Rajashekar, Anirudh; Viboudoulou Vilpoux, Mervy Ever; Wieser, Christina. 2021. Spatial Heterogeneity of COVID-19 Impacts on Urban Household Incomes: Between- and Within-City Evidence from Two African Countries. Policy Research Working Paper; No. 9762. World Bank, Washington, DC. ( ) World Bank. https://openknowledge.worldbank.org/handle/10986/36227 License: CC BY 3.0 IGO."

13. Li, Ling, and Wan, Li, Understanding the Spatial Impact of COVID-19: New Insights from Beijing after One Year into Post-Lockdown Recovery (August 20, 2021). Available at SSRN: https://ssrn.com/abstract=3908277 or http://dx.doi.org/10.2139/ssrn.3908277Where is Ethiopia in the World? https://worldpopulationreview.com

14. Mollo, A.; Vahedib, B.; Rivera, K. GIS-based spatial modeling of COVID-19 incidence rate in the continental United States. Sci.Total Environ. 2020, 728, 138884. [

15. Sarwar, S.; Waheedab, R.; Sarwar, S.; Khand, A. COVID-19 challenges to Pakistan: Is GIS analysis useful to draw solutions? Sci. Total Environ. 2020, 730, 139089.

16. Dong, N.; Yang, X.; Ye, L.; Chen, K.; Chan, E.; Yang, M.; Chen, C. Genomic and protein structure modeling analysis depicts the origin and infectivity of 2019-to, a new coronavirus that caused a pneumonia outbreak in Wuhan, China. bioRxiv 2020.

17. Arab-Mazar, Z.; Sah, R.; Rabaan, A.A.; Dhama, K.; Rodriguez-Morales, A.J. Mapping the incidence of the COVID-19 hotspot in IranImplications for travelers. Travel Med. Infect. Dis. 2020, 38, 1477-8939.

18. Rezaei, M.; Nouri, A.A.; Park, G.S.; Kim, D.H. Application of geographic information system in monitoring and detecting the COVID-19 outbreak. Iran. J. Public Health 2020, 49, 114-116. 
19. Giuliani, D.; Dickson, M.M.; Espa, G.; Santi, F. Modelling and Predicting the Spatio-Temporal Spread of Coronavirus Disease 2019 (COVID-19) in Italy (3/20/2020). SSRN 2020.

20. COVID19 - Ethiopia - Ethiopian Health Data https://ethiopianhealthdata.org > COVID-19 Ethiopia Case Tracker Dashboard

21. Alene KA, Gelaw YA, Fetene DM, et al. COVID-19 in Ethiopia: a geospatial analysis of vulnerability to infection, case severity, and death. BMJ Open 2021;11:e044606. doi:10.1136/ BMJ open-2020-044606

22. Where is Ethiopia in the World? https://worldpopulationreview.com

23. Ethiopia Population 2021 (Demographics, Maps, Graphs)". Archived from the original on 23 May 2021. Retrieved 23 May 2021

24. Lyons, Terrence (1996). "Closing the Transition: The May 1995 Elections in Ethiopia". Journal of Modern African Studies. 34 (1): 135. doi:10.1017/S0022278X00055233. JSTOR 161741

25. Jones SG, Kulldorff M. Influence of spatial resolution on space-time disease cluster detection. PLoS One. 2012;7(10):e48036

26. Kulldorff M. SaTScanTM User Guide for version 9.2. 2010

27. Alemu K, Worku A, Berhane Y. Malaria infection has spatial, temporal, and spatiotemporal heterogeneity in unstable malaria transmission areas in northwest Ethiopia. PLoS One. 2013;8(11):e79966

28. Zhao F, Cheng S, He G, Huang F, Zhang H, Xu B, et al. Space-time clustering characteristics of tuberculosis in China, 2005-2011. PLoS One. 2013;8(12):e83605.,

29. Areias C, Briz T, Nunes C. Pulmonary tuberculosis space-time clustering and spatial variation in temporal trends in Portugal, 2000-2010: an updated analysis. Epidemiol Infect. 2015;143(15):3211-9.,

30. Wang WL, Wang HJ, Deng Y, Song T, Lan JM, Wu GZ, et al. Serological Study of An Imported Case of Middle East Respiratory Syndrome and His Close Contacts in China, 2015. Biomed Environ Sci. 2016;29(3):219-23.

31. Zhang WY, Wang LY, Liu YX, Yin WW, Hu WB, Magalhaes RJ, et al.Spatiotemporal transmission dynamics of hemorrhagic fever with renal syndrome in China, 2005-2012. PLoS Negl Trop Dis. 2014;8(11):e3344.

32. Zeleke Geto et al. The Escalating Magnitude of COVID-19 Infections among the Northeastern Ethiopia Region: A Community-Based Cross-Sectional Study International Journal of Microbiology Volume 2021, Article ID 5549893, 9 pages https://doi.org/10.1155/2021/5549893

33. Paltiel AD, Zheng A, Walensky RP. Assessment of SARS-CoV-2 screening strategies to permit the safe reopening of college campuses in the United States. JAMA Netw Open 2020;3:e2016818. https://doi.org/10.1001/jamanetworkopen.2020.16818 PMID:32735339

34. Lanier WA, Babitz KD, Collingwood A, et al. COVID-19 testing to sustain in-person instruction and extracurricular activities in high schools-Utah, November 2020-March 2021. MMWR Morb Mortal Wkly Rep 2021;70:785-91. https://doi.org/10.15585/mmwr.mm7021e2 PMID:34043614

35. Bagchi S, Mak J, Li Q, et al. Rates of COVID-19 among residents and staff members in nursing homes-United States, May 25November 22, 2020. MMWR Morb Mortal Wkly Rep 2021;70:52-5. https://doi.org/10.15585/mmwr.mm7002e2 PMID:33444301

36. Wallace M, Hagan L, Curran KG, et al. COVID-19 in correctional and detention facilities-United States, February-April 2020. MMWR Morb Mortal Wkly Rep 2020;69:587-90. https://doi.org/10.15585/mmwr.mm6919e1 PMID:32407300

37. Mosites E, Parker EM, Clarke KEN, et al.; COVID-19 Homelessness Team. Assessment of SARS-CoV-2 infection prevalence in homeless shelters-four U.S. cities, March 27-April 15, 2020. MMWR Morb Mortal Wkly Rep 2020;69:521-2.

https://doi.org/10.15585/mmwr.mm6917e1 PMID:32352957e

38. Waltenburg MA, Victoroff T, Rose CE, et al.; COVID-19 Response Team. Update: COVID-19 among workers in meat and poultry processing facilities-United States, April-May 2020. MMWR Morb Mortal Wkly Rep 2020;69:887-92. https://doi.org/10.15585/mmwr.mm6927e2 PMID:32644986

39. Moghadas SM, Fitzpatrick MC, Sah P, et al. The implications of silent transmission for the control of COVID-19 outbreaks. Proc Natl Acad Sci U S A 2020;117:17513-5. https://doi.org/10.1073/pnas.2008373117 PMID:32632012

40. Johansson MA, Quandelacy TM, Kada S, et al. SARS-CoV-2 transmission from people without COVID-19 symptoms. JAMA Netw Open 2021;4:e2035057. https://doi.org/10.1001/jamanetworkopen.2020.35057 PMID:33410879)

\section{Figures}




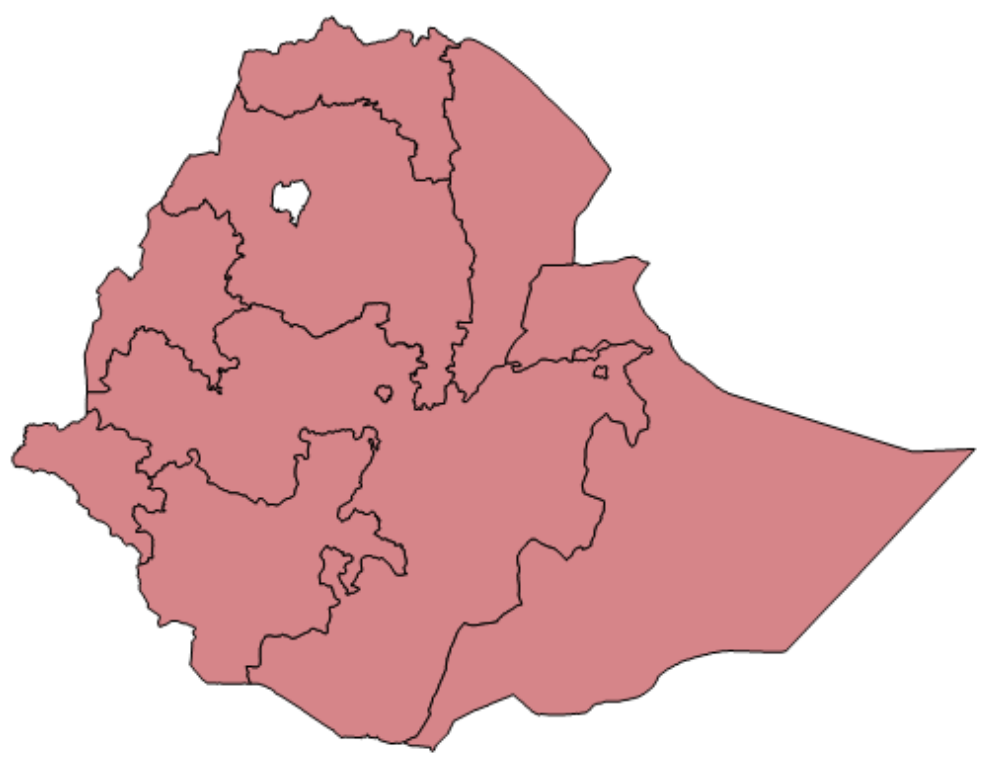

Figure 1

\section{Study map}

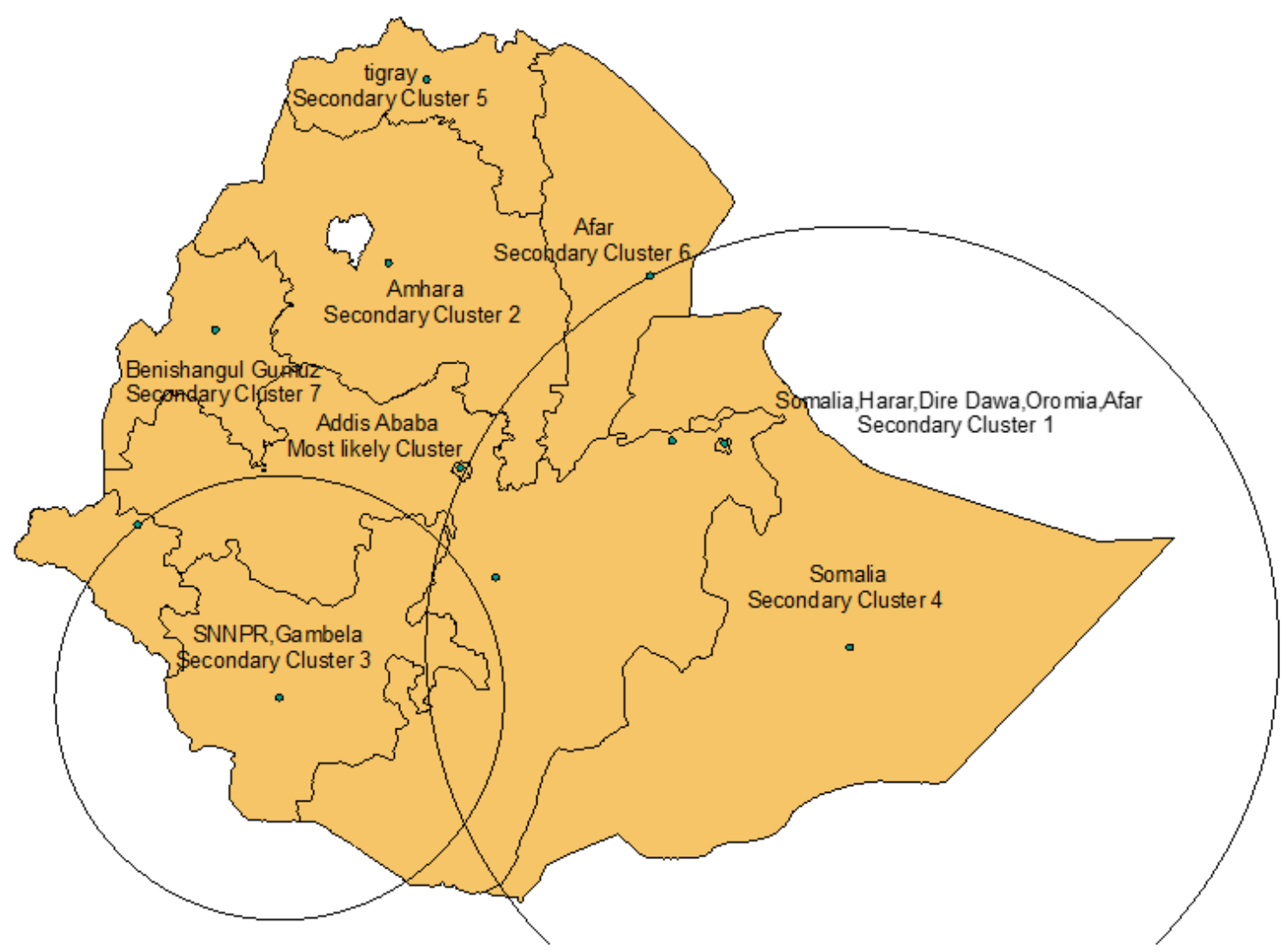

Figure 2

Spatial clustering of COVID 19 in Ethiopia 


\section{Detected Cluster}

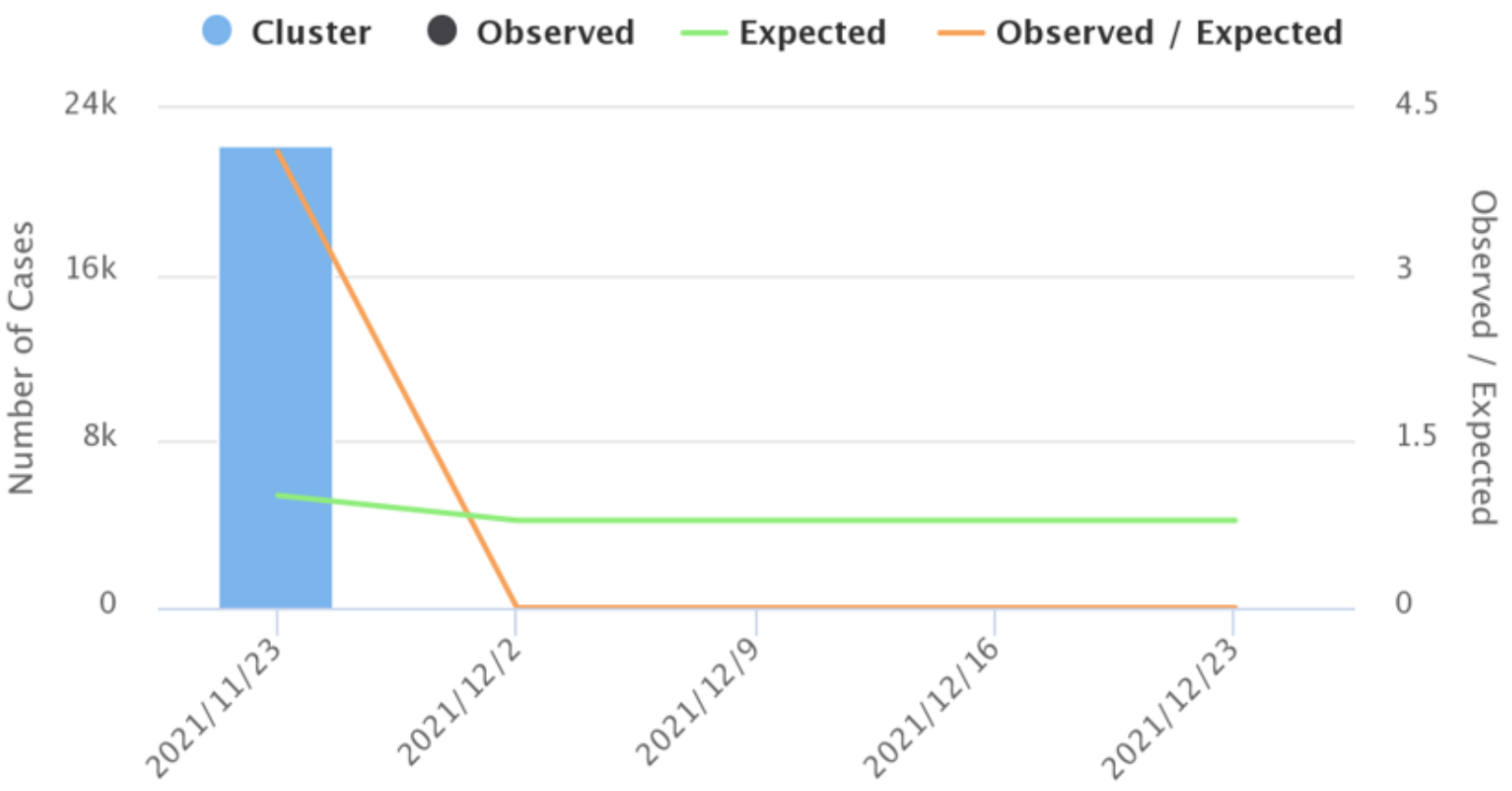

Figure 3

Temporal graph 


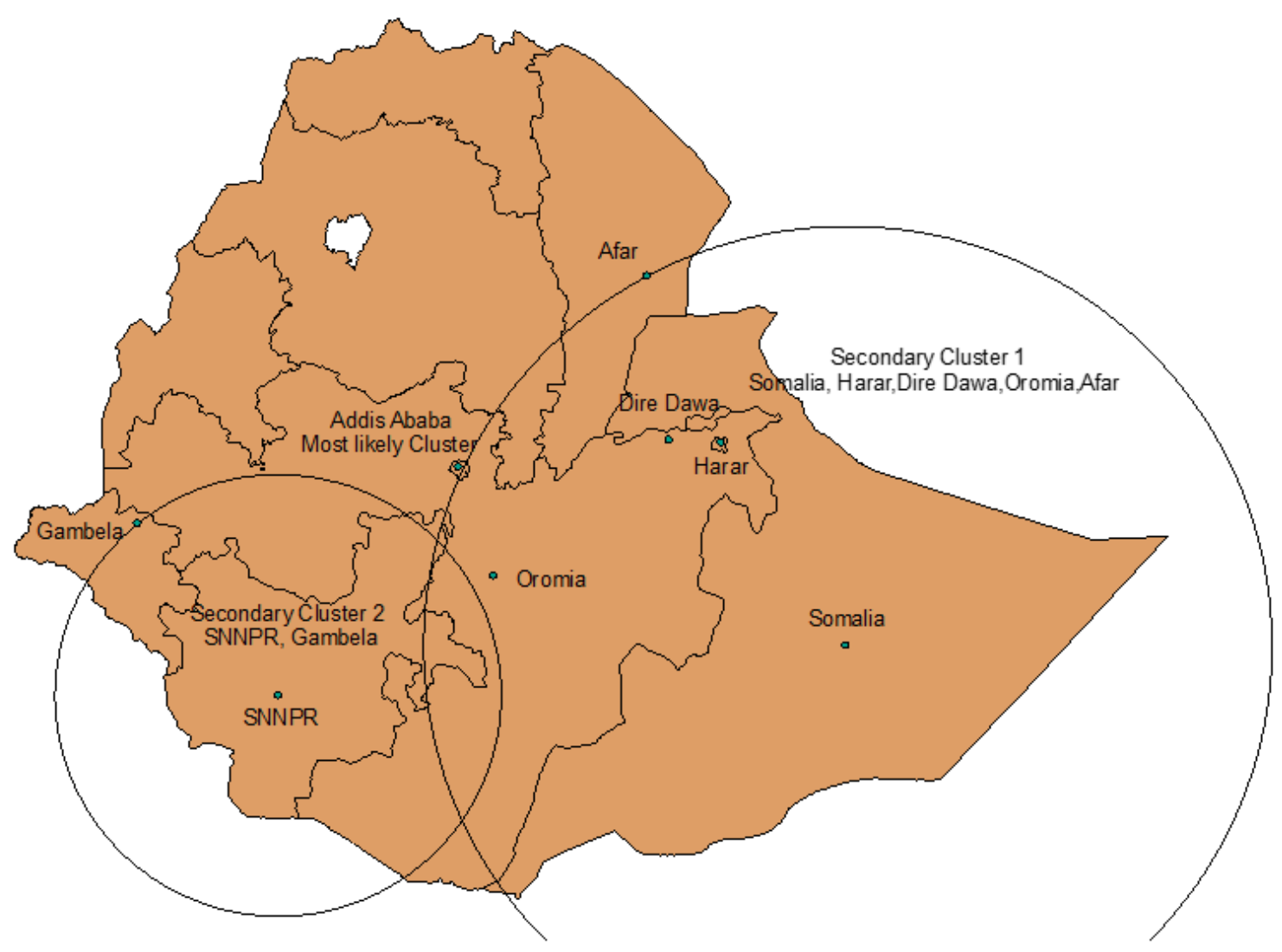

Figure 4

Spatiotemporal clusters of COVID 19 in Ethiopia 